\title{
ANALISIS KESULITAN DALAM MATERI STATISTIKA DITINJAU DARI KEMAMPUAN PENALARAN DAN KOMUNIKASI STATISTIS
}

\author{
Iyam Maryati ${ }^{1}$, Nanang Priatna ${ }^{2}$ \\ ${ }^{1}$ Sekolah Tinggi Keguruan dan Ilmu Pendidikan Garut \\ maryati_iyam@student.upi.edu \\ ${ }^{2}$ Universitas Pendidikan Indonesia, Indonesia \\ nanang_priatna@upi.edu
}

\begin{abstract}
The purpose of this study was to analyze the difficulty of learning mathematics experienced by junior high school students in solving problems in statistical materials. This research is a qualitative descriptive research with data collection technique by using test and interview while the validity of data by using technique triangulation. Data analysis through several stages of data collection phase, data reduction phase, data presentation stage, and conclusion drawing stage. This research was conducted on students of class VIII Madrasah Tsanawiyah Negeri Garut academic year 2016/2017. The results of this study indicate that the types of difficulties experienced by students are: 1) presents statistical statements in oral, written form, tables, diagrams, and graphs (for communication); 2) field allegations; 3) performs statistical manipulations; 4) compile the evidence, give reasons for the correctness of the solution; 5) draw a conclusion; 6) examine a valid argument; 7) find patterms or traits of statistical symptoms to make generalizations. While the factors that can affect student learning difficulties in addition to internal factors of students that is 1) lack of early understanding of the material about statistics and 2) the motivation of students in following the teaching and learning process. While the external factors that affect student learning difficulties are: 1) the classroom environment is a) lack of facilities and infrastructure that can support students in understanding the subject matter, $b$ ) the lesson model applied less motivate the students to learn actively and creatively in understanding the material lessons, 3) the family environment is less supportive in creating a conducive atmosphere to provide opportunities for students to do home study, and 4) the community environment is an uncomfortable environment for students to perform activities that are wide-ranging insights.
\end{abstract}

Keywords: Analysis of Difficulties, Statistical Communication, and Reasoning Ability

\begin{abstract}
ABSTRAK
Tujuan dari penelitian ini adalah untuk menganalisis kesulitan matematika yang dialami siswa SMP dalam memecahkan masalah dalam materi statistik pembelajaran. Penelitian ini merupakan penelitian deskriptif kualitatif dengan teknik pengumpulan data dengan menggunakan uji dan wawancara sedangkan validitas data dengan menggunakan teknik triangulasi. Analisis data melalui beberapa tahap dari tahap pengumpulan data, tahap reduksi data, tahap penyajian data, dan penarikan kesimpulan panggung. Penelitian ini dilakukan pada siswa kelas VIII Madrasah Tsanawiyah Negeri Garut tahun akademik 2016/2017. Hasil penelitian ini menunjukkan bahwa jenis kesulitan yang dialami oleh siswa adalah: 1) menyajikan laporan statistik secara lisan, tertulis, tabel, diagram, dan grafik (untuk komunikasi); 2) dugaan lapangan; 3) melakukan manipulasi statistik; 4) menyusun bukti, memberikan alasan atas kebenaran solusi; 5) menarik kesimpulan; 6) memeriksa argumen yang valid; 7) menemukan patterms atau ciri-ciri gejala statistik untuk
\end{abstract}


membuat generalisasi. Sedangkan faktor-faktor yang dapat mempengaruhi kesulitan belajar siswa selain faktor internal siswa yang 1) kurangnya pemahaman awal materi tentang statistik dan 2) motivasi siswa dalam mengikuti proses pengajaran dan pembelajaran. Sedangkan faktor eksternal yang mempengaruhi kesulitan belajar siswa adalah: 1) lingkungan kelas adalah) kurangnya sarana dan prasarana yang dapat mendukung siswa dalam memahami materi pelajaran, b) model pembelajaran yang diterapkan kurang memotivasi siswa untuk belajar aktif dan kreatif dalam memahami pelajaran materi, 3) lingkungan keluarga kurang mendukung dalam menciptakan suasana kondusif untuk memberikan kesempatan bagi siswa untuk melakukan belajar di rumah, dan 4) lingkungan masyarakat adalah lingkungan tidak nyaman bagi siswa untuk melakukan kegiatan yang luas wawasan.

Kata Kunci: Analisis Kesulitan, Penalaran dan Komunikasi statistik

\section{PENDAHULUAN}

Dalam kurikulum pendidikan nasional kita, materi pembelajaran statistik telah diberikan mulai dari tingkat sekolah dasar hingga tingkat perguruan tinggi. Bahan statistik ini diintegrasikan ke dalam mata pelajaran matematika diberikan di tingkat SD hingga SMA. Sementara dalam statistik perguruan tinggi dipelajari dalam mata kuliah khusus. Dalam materi statistik yang diberikan kepada siswa SMP kelas 8, siswa diwajibkan untuk dapat menyajikan data dalam diagram batang, garis, dan lingkaran. Kemampuan ini sangat berguna bagi siswa dalam memahami informasi data. Dalam kehidupan sehari-hari, banyak data yang disajikan dalam bentuk diagram. Misalnya, ketika siswa memasuki ruang administrasi yang mereka lihat di papan diagram jumlah siswa, guru, dan karyawan yang berada di sekolah. Mereka akan dapat memahami informasi jika mereka memiliki kemampuan untuk menyajikan data dalam bentuk diagram. Kemampuan untuk menyajikan data ini adalah kemampuan penalaran dan komunikasi statistik.

Tapi dalam memahami ide-ide statistik dalam konten informasi sering siswa memahami kurang sempurna. Hal ini dapat dilihat ketika siswa memecahkan masalah statistik yang tidak lengkap. Tidak terpenuhi ini dianggap karena kurangnya kemampuan siswa dalam menyampaikan ide statistik secara lisan, tertulis, tabel, grafik, dan diagram. Ketidakmampuan siswa dalam menyajikan data atau ide-ide statistik yang dapat dilihat dari hasil replikasi formatif masih rendah. Tujuan dari penelitian ini adalah untuk menggambarkan kesulitan belajar dalam memahami data atau ide-ide statistik pada siswa Madrasah Tsanawiyah dalam hal komunikasi statistik dan kemampuan penalaran.

Menurut (JB Garfield, 2002) menyatakan penalaran statistik adalah cara seseorang bekerja dengan menggunakan ide-ide statistik dan memahami informasi statistik. Sedangkan (Joan Garfield, Le, Zieffler, \& Ben-Zvi, 2014) menjelaskan bahwa penalaran statistik melibatkan interpretasi keputusan berdasarkan kumpulan data, representasi data, 
atau ringkasan data statistik.(Lovett, 2001) Berdasarkan negara penelitiannya dalam memahami dan meningkatkan penalaran statistik siswa, dilakukan dengan mengintegrasikan tiga pendekatan, pendekatan yaitu teoritis studi, studi empiris, dan penelitian berbasis kelas. (Dasari, 2009) Kemampuan penalaran statistik adalah kemampuan untuk menarik kesimpulan dan memberikan penjelasan berdasarkan orientasi data yang berkenaan dengan prosedur terstruktur, prosedur terstruktur, dan konsep statistik dan memberikan komentar kritis pada proses atau hasil statistik. Menurut (Maryati, 2017) dalam tinjauan literatur berpendapat bahwa kemampuan penalaran statistik adalah kemampuan untuk memahami informasi dalam kehidupan sehari-hari berdasarkan data atau ide-ide yang berarti kemampuan untuk memahami bagaimana memilih, hadir, mengurangi, dan menyajikan data yang digunakan dalam masalah yang ada.

Kemampuan komunikasi statistik sebagai proses membangun pengetahuan statistik juga dapat dikembangkan dalam statistik pembelajaran pengantar. Menurut (Jones et al., 2001) bahwa meskipun rekomendasi untuk penciptaan visi pengajaran matematika ditekankan pada kemampuan pemecahan masalah, penalaran, dan bukti. Sebuah aspek penting dari keterampilan komunikasi matematika adalah kemampuan untuk berkomunikasi konsep dan hasil dalam bentuk tertulis dan lisan. (Parke, 2008) bahwa keterampilan komunikasi setiap orang dalam membaca, menulis, menunjukkan, dan menunjukkan informasi statistik.

Dalam penelitian ini, kemampuan penalaran statistik dan kemampuan komunikasi statistik diukur secara bersamaan. Dalam Permendiknas Tahun 2006 tentang standar isi mata pelajaran mata pelajaran matematika SMP MTs, kompetensi inti terdiri dari kemampuan: 1) pemahaman konsep, 2) penalaran, 3) komunikasi, 4) pemecahan masalah, dan 5) apresiasi pada kegunaan matematika. Kompetensi ini merupakan satu kesatuan menjaga terpadu diingat bahwa kompetensi didefinisikan sebagai pengetahuan bulat, keterampilan dan sikap berarti bahwa lima tujuan merupakan satu kesatuan. (Wardhani, 2010) Indikator dalam mencapai penalaran dan komunikasi kemampuan adalah: 1) pernyataan hadir dengan lisan, tulisan, grafik, tabel, dan diagram, 2) menunjukkan, 3) memanipulasi, bukti 4) kompilasi, memberikan alasan atau bukti kebenaran solusi, 5) kesimpulan gambar dari pernyataan, 6) memeriksa validitas argumen, 6) menemukan pola atau sifat dari gejala statistik untuk membuatgeneralisasi. 


\section{METODOLOGI PENELITIAN}

Penelitian Data diperoleh dari 37 siswa dari 8 kelas tahun akademik 2016/2017 Madrasah Tsanawiyah Garut. Untuk mengumpulkan informasi tentang kesulitan siswa dalam materi statistik berasal dari hasil tes kemampuan penalaran dan komunikasi statistik. Sebagai siswa data pendukung diberi kuesioner yang menyediakan informasi tentang kesulitan siswa dalam belajar statistik deskriptif. Selain memberikan kuesioner, sebelum melakukan tes penalaran dan keterampilan komunikasi statistik, peneliti melakukan wawancara dengan siswa untuk mendapatkan informasi lebih lanjut tentang kesulitan siswa dalam mempelajari materi statistik. Data yang diamati dikumpulkan dari kuesioner, tes kesalahpahaman, dan tes penalaran statistik siswa dianalisis melalui langkah-langkah berikut:

1) Lakukan tabulasi data tentang kesulitan belajar yang dihadapi siswa dalam materi statistik.

2) Mengklasifikasikan jenis siswa kesulitan mengalami

3) kemampuan penalaran Klasifikasikan dan komunikasi statistik.

4) Hadir tes statistik deskriptif penalaran dan keterampilan komunikasi statistik.

\section{HASIL DAN PEMBAHASAN}

Analisis Awal hasil pengamatan dari kuesioner dan wawancara siswa yang mengalami kesulitan yang mereka alami selama proses pembelajaran:

1. Mengalami kesulitan dalam mengenali dan mengklasifikasi jenis data dan menampilkan mereka pada grafik atau tabel.

2. Kurang pemahaman tentang bagaimana mengajukan tuduhan.

3. Masih mengalami kebingungan dalam menarik kesimpulan, menyusun bukti, memberikan alasan atau bukti terhadap kebenaran solusi,

4. buruk dipahami dengan benar menarik kesimpulan dari pernyataan,

5. Maklum dalam memeriksa validitas argumen,

6. Kurang tahu bagaimana untuk menemukan pola atau sifat dari fenomena matematika untuk membuat generalisasi.

Hasil analisis kesulitan siswa akan digunakan sebagai patokan atau referensi untuk mempersiapkan bahan ajar dan pemilihan model pembelajaran yang tepat sesuai dengan 
karakteristik bahan statistik berdasarkan kendala yang dialami oleh siswa dalam proses pembelajaran sehingga dapat meningkatkan siswa penalaran dan komunikasi statistik.

Ringkasan data pengamatan mahasiswa program pendidikan matematika untuk variabel uji kesalahpahaman dan kemampuan penalaran statistik siswa dapat digambarkan dalam sebuah tabel sebagai berikut:

Tabel 1. Nilai Penalaran dan Komunikasi Statistik

\begin{tabular}{cccccc}
\hline Variabel & N & Minimum & Maximum & Rata-rata & Simpangan Baku \\
\hline Penalaran dan Statistik & 37 & 30 & 83 & 52,8 & 8,5 \\
Kemampuan komunikasi & & & & & \\
\hline
\end{tabular}

Kemampuan penalaran dan komunikasi siswa memiliki rentang yang sangat luas, antara skor terendah dengan skor tertinggi 53 dengan rata-rata 52,8 dan standar deviasi 8,5 Bila menggunakan skor standar 65 sebagai nilai minimal pencapaian standar kompetensi mata pelajaran matematika di kelas akan terlihat bahwa nilai rata-rata dari penalaran dan uji statistik di bawah standar kompetensi minimal. Nilai ini memberikan informasi bahwa kemampuan penalaran siswa dan komunikasi statistik masih rendah.

Hasil analisis kesulitan dalam hal kemampuan penalaran statistik seperti yang ditunjukkan pada tabel berikut:

Tabel 2. Hasil Kemampuan Penalaran dan Komunikasi Statistik Siswa

\begin{tabular}{|c|c|c|c|}
\hline \multirow[t]{2}{*}{ No } & \multirow[t]{2}{*}{ Kemampuan Penalaran dan Komunikasi Statistik diukur } & \multicolumn{2}{|c|}{$\%$} \\
\hline & & Benar & Salah \\
\hline 1. & $\begin{array}{l}\text { menyajikan pernyataan matematika dengan lisan, tertulis, } \\
\text { tabel, gambar, diagram }\end{array}$ & 54 & 46 \\
\hline 2. & tuduhan yang diajukan & 55 & 45 \\
\hline 3. & melakukan manipulasi statistik & 34 & 66 \\
\hline 4. & $\begin{array}{l}\text { menyusun bukti, memberikan alasan atau bukti terhadap } \\
\text { kebenaran } \\
\text { solusi }\end{array}$ & 30 & 70 \\
\hline 5. & menarik kesimpulan dari pernyataan & 47 & 53 \\
\hline 6. & cek keabsahan argumen & 37 & 63 \\
\hline 7. & $\begin{array}{l}\text { pola find atau ciri-ciri gejala statistik untuk membuat } \\
\text { generalisasi }\end{array}$ & 28 & 72 \\
\hline
\end{tabular}

Pada Tabel 2 menunjukkan bahwa kemampuan penalaran dan statistik komunikasi di mengkategorikan data dengan penyajian laporan matematika dengan lisan, ditulis, tabel, gambar, diagram yang dijawab dengan benar oleh $54 \%$ dan yang menjawab salah dengan 46\%. Penalaran dan statistik komunikasi mengenai tuduhan pengajuan adalah 55\% yang menjawab dengan benar dan $45 \%$ menjawab tidak benar. Dalam kemampuan penalaran dan komunikasi statistik tentang penalaran untuk melakukan statistik memanipulasi ada 
$34 \%$ yang menjawab dengan benar dan oleh $66 \%$ yang menjawab salah. kompilasi bukti, memberikan alasan atau bukti untuk kebenaran dari solusi ada 30\% yang menjawab dengan benar dan $70 \%$ yang menjawab salah. Untuk mengukur penalaran siswa dan komunikasi statistik dalam hal penalaran, kesimpulan dari laporan adalah $47 \%$ yang menjawab dengan benar dan $53 \%$ menjawab salah. Sementara dalam kemampuan untuk memeriksa validitas argumen ada $37 \%$ menjawab dengan benar dan $63 \%$ yang menjawab salah. Dan terakhir, dalam kemampuan untuk menemukan pola atau sifat dari gejala statistik untuk membuat generalisasi, ada $28 \%$ yang menjawab dengan benar dan $72 \%$ yang menjawab salah.

\section{KESIMPULAN}

Uraian tentang kesulitan dalam materi statistik pada siswa SMP kelas 8 berdasarkan hasil pengamatan memiliki persentase di bawah standar kompetensi. Meskipun hasil penelitian ini tidak dapat digunakan sebagai alat untuk menggeneralisasi penalaran dan komunikasi statistik kemampuan siswa tetapi penulis memberikan referensi sebagai salah satu referensi dalam menentukan dan mendefinisikan metode pembelajaran yang akan diterapkan sehingga kesulitan siswa dapat diminimalkan dan penalaran dan komunikasi statistik siswa dapat ditingkatkan.

\section{REFERENSI}

Dasari, D. (2009). Meningkatkan Kemampuan Penalaran Statistis Mahasiswa melalui Pembelajaran Model PACE. Disertasi SPS UPI.

Garfield, J. (2002). The challenge of developing statistical reasoning. Journal of Statistics Education.

Garfield, J., Le, L., Zieffler, A., \& Ben-Zvi, D. (2014). Developing students' reasoning about samples and sampling variability as a path to expert statistical thinking. Educational Studies in Mathematics, 1-16. https://doi.org/10.1007/s10649-0149541-7

Jones, G. A., Langrall, C. W., Thornton, C. A., Mooney, E. S., Wares, A., Jones, M. R., ... Nisbet, S. (2001). Using students' statistical thinking to inform instruction. Journal of Mathematical Behavior, 20(1), 109-144. https://doi.org/10.1016/S0732-3123(01)00064-5

Lovett, M. (2001). A Collaborative Convergence on Studying Reasoning Processes: A case Study in Statistics. Cognitive and Instruction: Twenty-Five of Progress ,Mahwah, NJ.

Maryati, I. (2017). Peningkatan Kemampuan Penalaran Statistis Siswa Sekolah Menengah Pertama melalui Pembelajaran Kontekstual. Mosharofa, 6(1), 129140.

Parke, S. (2008). Reasoning and Communicating in the Language of Statistics. Journal of Statistics Education, 16. 
Jurnal PRISMA Universitas Suryakancana

Wardhani, S. (2010). Teknik Pengembangan Instrumen Penilaian hasil belajar di SMP/MTs, 1-35. 